\title{
Food as an Energy Resource: \\ Patterns of Accumulation and Use of Products in Chukotka
}

\author{
Elena A. Davydova* \\ Peter the Great Museum of Anthropology \\ and Ethnography (Kunstkamera) RAS \\ 3 University emb., St. Petersburg, 199034, Russia \\ Chukotka branch of North-Eastern Federal University \\ 3 Studencheskaia Str., Anadyr, 689000, Russia
}

Received 02.03.2019, received in revised form 30.07.2019, accepted 09.08.2019

The article investigates the changes in Chukotka residents' diet during $20^{\text {th }}-21^{\text {st }}$ centuries. The paper analyzes the archival and field materials related mainly to reindeer herders of the Amguema tundra. By comparing traditional and modern food practices in this local place I focus on the ways of acquiring, preserving, processing, and preparing food resources. The paper argues that the shifts in food practices and diet were accompanied by a transition to a new food autonomy regime. Today, as in the previous time, people aim to create nourishing, tasty and diverse food. In the pre-Soviet period people achieved this goal through the use of various cooking technologies, accumulation of local resources, and social ties with coastal Chukchi. Now, along with the listed strategies, they maximize their food resources due to purchased (but not home-made) products. As a result, a network of relations with the reindeer enterprise, state infrastructure, trade companies, material components of mobility, and mutual relations between the tundra and the village influence people's sense of food security and ultimately limits their food autonomy.

Keywords: anthropology of food, energy, resources, reindeer herding, indigenous people, Chukotka, Arctic region.

The research was supported by the Russian Science Foundation (project No. 17-78-10125).

Research area: ethnography, ethnology, anthropology.

Citation: Davydova, E.A. (2019). Food as an energy resource: patterns of accumulation and use of products in Chukotka. J. Sib. Fed. Univ. Humanit. soc. sci., 12(8), 1408-1424. DOI: $10.17516 / 1997-1370-0457$.

(c) Siberian Federal University. All rights reserved

* Corresponding author E-mail address: elenav0202@gmail.com ORCID: 0000-0002-9299-7551

This work is licensed under a Creative Commons Attribution-NonCommercial 4.0 International License (CC BY-NC 4.0). 
This article investigates food system transformations in Chukotka in the $20^{\text {th }}-21^{\text {st }}$ centuries. Considering food as a source of energy allows us to show different patterns of acquisition and use of food resources in the historical perspective. First, we compare traditional and modern nutrition and reveal food-related values and perceptions affecting the local residents' practices. Further, the focus of the research shifts to the ways of acquiring and preserving the food resource, the analysis of which allows to identify the food autonomy regimes that existed in Chukotka in different socio-historical contexts.

The research is based on the field materials collected in Anadyr (the capital of Chukotka autonomous region), Egvekinot (the center of Iul'tin region), Amguema (reindeer village) and the Amguema tundra in 2017 and 2018. Moreover, I use the archival materials relating to Iul'tin region of Chukotka Autonomous Okrug, the place of most of my field work. Thus, the archival sources were 1) field diaries of V.G. Kuznetsova, a Leningrad ethnographer who was living with Amguema reindeer herders for three years (from 1948 to 1951) and 2) documents of village councils of Iul'tin region of Chukotka from the archive of Egvekinot okrug administration. This source base, focused on one place but absorbing different historical periods, makes it possible to trace the dynamics of food changes during the $20^{\text {th }}-21^{\text {st }}$ centuries.

\section{Change of food patterns in Chukotka in the second half of the $\mathbf{2 0}^{\text {th }}$ century: the perception of fullness and taste}

In his time V.G. Bogoraz wrote that "the Chukchi menu is not very diverse" (Bogoras, 1904: 199). However, V.G. Kuznetsova's notes and modern ethnographic studies (Afanas'eva, Simchenko, 1993: 56-100; Golbtseva, 2017: 249-270), in contrast, state the variety of dishes cooked by the herders. Indeed, despite the fact that most of them were made from parts of reindeer, cooking technologies used in combination with products from local resources (those of marine mammal hunting, gathering, fishing, and hunting) resulted in creating the diet diverse in taste and having highly nourishing qualities.

Comparing the reindeer herders' diet of the pre-Soviet period with the current situation, several key points can be noted. Many dishes are completely out of use. For example, ril'kyril', that formerly was a daily food, is, as a rule, thrown away nowadays; blood that was previously preserved is collected sometimes but is used mainly for cooking for the dogs; a few housewives render the bone fat today. Other

\footnotetext{
The content of a reindeer stomach for daily cooking of porridge.
} 
dishes such as rorat ${ }^{1}$, prerem $^{2}$, nat'iet ${ }^{3}$, kemeiyryn ${ }^{4}$ are used in a ritual context or when people start feeling nostalgic for the taste of the Chukchi food that reminds them about their childhood. In this regard, today, traditional food is preserved in smaller volumes: for example, previously the family needed at least a whole seal bag (pygpyg) of kemeiyryn whereas one plastic bag is enough for them today.

At the same time, through the system of boarding schools and state supplies of products to reindeer herders the Soviet cuisine was integrated into the local diet. In other words, the people's taste preferences changed (Kozlov, Nuvano, Vershubsky, 2007: 105). Justifying their food preferences that include European products people say: "This is because we are from boarding schools" (Davydova, 2017, 2018).

Despite significant changes in the people's diet, two principles that previously permeated local residents' food practices and perceptions significantly affect their food system and even organize it in a certain way to the present day. The first important aspect of the reindeer herders' nutrition is associated with perception of satiety and nutritional value of food. A key characteristic of the local residents' food, which determines the quality and value of a dish, is its capacity to nourish. It is noteworthy that, according to Sh. Vensten's thematic dictionary, the concepts of 'delicious' and 'fat' can be nominated by one word in the Chukchi language. For example, " $n$ 'yrgyroolk' $y l$ " can be translated either "delicious food" or "fatty food".

N.F. Kallinikov wrote that for reindeer herders the fatter a piece of meat is the better it is (Kallinikov, 1912: 100). Examples of such attitude to food can be found in V. G. Kuznetsova's diaries. The master of yaranga, Tymnenentyn, reproached a girlworker for tastelessly cooked kivlet,_— "Watery, without fat", he said'. Yatgyrgin, a young shepherd, who sometimes stole food, tried to steal the fattest piece of meat ${ }^{7}$.

Even today Chukchi have their ideas about the value of substantial food. In this regard, as half a century ago, numerous meat dishes, which are considered the most nutritious and are in no way comparable to European carbohydrate food, form the basis of the tundra diet. Looking at the lunch I cooked once again, the cook, who accompanied the reindeer breeders in summer (when the reindeer are grazed in the summer pastures - the author's note), joked: “If I was cooking like you (that is using

\footnotetext{
The part of a stomach stuffed with ground meat and fat.

Ground and frozen meat with fat.

Reindeer lip and hooves roasted on fire and made sour in blood.

Fermented and further frozen mixture of willow leaves and the content of a reindeer stomach.

Available at: http://charles.weinstein.free.fr/chukches/LEX/LxT-Tajnat_aliment.html

AMAE. F. K-1, inv. 2, file 376, 1. 13.

AMAE. F. K-1, inv. 2, d. file 377, 1. 2-2 back page.
} 
little meat and fat - the author's note), the shepherds would put this pan on my head" (Davydova, 2018).

Newcomers also pay attention to the local residents' taste preference for fatty foods. In particular, they are surprised that Chukchi do not appreciate the "delicious dietary" parts of reindeer meat and, thus, prefer "tasteless" pieces with a lot of fat to them. It is the nutritional value of the dish that is one of the criteria by which the indigenous people divide food into Russian and Chukchi, and it is the latter (the authentic one) that is attributed exclusively positive properties. A. Appadurai noted that authentic food cannot have bad qualities (Appadurai, 1986: 25). According to local people, Russian food is not nourishing and leaves a person hungry whereas a small amount of Chukchi food keeps a person full for a long time. These features of Russian and Chukchi food were also described by S. Yamin-Pasternak and her co-authors in relation to the Bering Strait region (Yamin-Pasternak et al., 2014: 625).

Especially high nutritional properties are attributed to fermented dishes, which, in the eyes of the local residents, are the most authentic food and a symbol of the Chukchi cuisine. People emphasize that any fermented food is very nutritious. It perfectly warms, even if served frozen. For example, in winter in the tundra reindeer herders eat dolbanina made from fermented frozen meat mixed with a seal fat. According to people, despite the fact that this dish is cold, it begins to warm a person from the inside. An informant, a former reindeer herder, recalled how he always went out of yaranga in winter without a hat after eating this food, as he was very hot as if steaming (Davydova, 2017).

In the tundra, it is especially important for people to eat food that is not just delicious, but also quickly and permanently nourishing. Long walks, cold, and labor activities requiring immediate performance are an integral part of the reindeer herders' life. As an Amguema reindeer herder once explained, one should be able to fill up quickly, because a reindeer will not wait (Davydova, 2018). He thereby wanted to say that the calm herd can at any time start moving, and this is what a human does not always foresee. In this regard, a reindeer herder should be ready to complete his rest, including the meal, at any moment. The skill of fast eating includes the ability to quickly cook nutritious food, quickly organize a feast and quickly eat the dishes cooked. For example, reindeer herders like to take kykvat'ol (air-dried meat) to the pasture. It does not need to be heated, and a small amount of this product nourishes quickly. Previously, the housewives cooked prerem for the road. Today, the reindeer herders can take canned meat of industrial production with them. 
Thus, cooking technologies allow people to accumulate energy properties of products. Fermentation, air-drying and freezing of the most nutritious parts of reindeer mixed with fat are examples of cooking high-calorie dishes (Kozlov, Nuvano, Vershubsky, 2007: 114).

However, people consider that food should be not just substantial and tasty, but also diverse in taste. The informants emphasize that they like feeling different tastes. The hostess of the yaranga I lived in for some time being in the tundra was very proud of her ability to cook delicious and varied food (every day she tried to cook something new), her knowledge of a large number of recipes (she knows both traditional Chukchi dishes and the delicacies of the Soviet/Russian cuisine), ability to use them in practice not only in the village, but also in the tundra (for example, cooking biscuits in yaranga).

Prior to collectivization and Sovietization of the tundra the range of tastes was expanded through the use of various processing and cooking technologies, knowledge of numerous recipes, combination of different products, use of wild-growing herbs, fish, meat of wild animals, and purchase of products during the exchange with coastal dwellers and cooperation with the Soviet authorities.

Today, the orientation towards maximization of tastes also exists. Yet, it is put into practice in some other way. Traditional technologies of processing and cooking food are still in use. However, firstly, new technologies peculiar for the Soviet cuisine appeared and were incorporated by the inhabitants of Chukotka. For example, the locals did not cook fried chopped meat (cutlets) before, but now it is an integral part of their menu both in the tundra and in the village. Secondly, they started using some traditional technologies more intensively, whereas other technologies, on the contrary, can sometimes pale in their significance. So, due to the spread of refrigerators and chests (freezers) freezing of products in the village is all the year round process. In summer, many people freeze fish, berries, mushrooms, herbs, and roots. Some housewives do not leave the above mentioned kemeiyryn until cold for its fermentation outside, but immediately put it into the fridge for freezing. Thus, freezing can sometimes be preferable over previous fermentation, air-drying, drying and smoking of products (Davydova, 2019: 143-161).

The variety of recipes used in cooking has not decreased. It has, probably, even increased as numerous dishes of the Soviet cuisine (soups, porridge, pastries, etc.) were added to the traditional Chukchi cuisine.

Gathering of wild plants in the summer season as well as fishing continues to be an important component of providing people with food resources both in the tundra 
and in the village. However, the composition of gathered wild plants has changed. In the pre-Soviet times, people hardly harvested berries, as they ate them fresh during summer (Bogoras, 1904: 198). People's attitude to mushrooms during the Soviet regime was transformed from "disgust" to "desire" (Yamin-Pasternak, 2008: 214222). Incorporation of the Soviet cuisine elements by local dwellers, on the one hand, and emergence of such material objects as sugar, salt, freezers, on the other hand, led to the intense collection of these very products. Berries are frozen and sugared; mushrooms are dried, salted, and frozen in large volumes. However, many people stopped collecting traditionally harvested herbs, leaves and roots; and some village inhabitants who continue their harvesting prefer to put the harvested herbs in the freezer instead of drying, soaking, boiling, and fermenting. It should also be noted that cultivation of vegetables and herbs in greenhouses and garden beds has been gaining popularity among the local population since the 1990s, and this trend continues to this day. In most cases, the owners of greenhouses are newcomers. Yet, indigenous people sometimes also begin to get involved in vegetable growing.

Exchange with the dwellers of Vankarem and Nutepel'men villages, that is, the coastal Chukchi, is still of great importance. Firstly, during summer reindeer herding some brigades come close to the villages. This allows them to exchange with the villagers. Secondly, many Amguema residents have relatives and friends in these coastal villages and they occasionally visit the region center and Amguema, bringing gifts with them - walrus, whale, seal meat and fat. Thirdly, official transport from Amguema to Vankarem and Nutepel'men delivers food to these villages, and the locals use this transport to send gifts. Finally, sea hunting and fishing products are purchased by "Amguema" reindeer herding enterprise to provide reindeer herders and other villagers with it.

Thus, all these modern practices and local knowledge contribute to achieving the variety of tastes and creating nourishing dishes. At that, as it was shown, they are somewhat different from practices and ideas of the pre-Soviet period. The main feature of the local residents' modern diet, which distinguishes it from the diet of 70 years ago, is, probably, spread of "European" products. Talking about modern food in the tundra, one reindeer herder joked that now "doshirak (fast food) has become a traditional food" (Davydova, 2018). In V. G. Kuznetsova's time reindeer herders had the opportunity to purchase mainly tea, tobacco, and, less frequently, sugar and flour at state trading enterprises. Simplicity of a set of products delivered to reindeer herders and hunters by the state is possible to imagine when referring to the Nutepel'men village council 
deputies' orders from June 3, 1954: "Comrade Zenkov, the head of Konergino trade and procurement base, shall be obliged to provide for the sale of food (tea, sugar, tobacco, biscuits, etc.) to the collective farm ..."'.

It should be noted that the Soviet authorities immediately set a goal to solve the problem of supplying reindeer herders and hunters. This issue was brought up at the meetings of the village council of the working-people's deputies from 1950-s at least ${ }^{2}$. Documents of those times are full of requirements, promises, and reports concerning the supply of the locals with the products. The phrases "to provide reindeer herders' brigades with food", "to provide hunters with food", "to provide for the sale of food to the collective farm...", "to provide for uninterrupted trade of the shop, to provide hunters with necessary goods", "we will be provided with bread", "reindeer herders were provided with food" make the rhetoric of document circulation of those years ${ }^{3}$.

The reports of the heads of trade and procurement bases and shops were regularly heard at the meetings of Nutepel'men village council of the working-people's deputies. The discussions of these institutions' work were not formal; on the contrary, they were always very emotional. These discussions give a feeling of the people's genuine involvement in these institutions' problems, the participants' desire to understand and take into account all the nuances and subtleties of their work. Hot disputes were conducted on a wide range of issues: from the organization of the delivery of goods through navigation, trade, and storage to the distribution of the received halva, alcohol dilution, sale of goods from under the counter, or the lack of a washbasin at the seller's and, thus, selling goods with dirty hands ${ }^{4}$. Through the village councils, trade and procurement bases, shops, navigation system and other institutions the state introduced new food into the people's daily lives and formed a new aesthetic and taste perception of food by the local residents.

And, indeed, during the Soviet period the set of consumed food and dishes expanded significantly. Today, reindeer herders eat cereals, pasta and flour products, canned food, butter, sweets, sometimes even vegetables, fruits, and dairy products.

\footnotetext{
Archive of the administration of Egvekinot city district. The 1954 records of the village council sessions, the resolutions of the sessions and materials to them. F. 1. L. 10.

2 Archive of the administration of Egvekinot city district. The 1954 records of the village council sessions, the resolutions of the sessions and materials to them.

3 Archive of the administration of Egvekinot city district. The 1954 records of the village council sessions, the resolutions of the sessions and materials to them. L. 4 back page, 7, 9 back page, 10 back page, 14 .

4 Archive of the administration of Egvekinot city district. The 1954 records of the village council sessions, the resolutions of the sessions and materials to them. F. 1. L. 19-39.
} 
The range of food in the village and in the city is even wider, and access to many "European" products is easier.

Thus, if previously most of the dishes were cooked from venison, and the kaleidoscope of flavors and a sense of satiation were achieved mainly through the use and combination of various processing and cooking technologies, nowadays a wide range of products available to people opens up new opportunities for creativity and experiments.

Here are some examples from the field to illustrate this process. While in Egvekinot, I met my friends Valeriia Tyneil'gina and Tamara Kymyl'kut, the herders. As their vacation was almost over, they were about to go to the reindeer herders' brigade and invited me with them. On the day of departure they asked to help them buy food for the tundra. They took a lot of different products that illustrate the changes in the people's diet: oranges, mayonnaise, potatoes, onions, cabbage, tomato paste, seasonings, etc. However, the purchase of a chicken was the strongest surprise for me. I wondered why they needed a chicken of rather dubious quality in the tundra full of fine fresh reindeer meat. Tamara replied that they like eating diverse food (Davydova, 2018).

Another memory relates to the conversation in Anadyr with a young man whose parents grew up in a reindeer herding families in Ryrkaypiy tundra. He said that he liked cooking, including Chukchi dishes. He showed me a group on WhatsApp social network, initiated by the representatives of the Indigenous Peoples of Chukotka organization. In it, the group members share their culinary tricks, and namely the interchangeability of different products in the recipes of certain dishes. My companion confessed that he periodically follows the group members' advice in replacing chicken with venison, raspberries with cloudberries, etc. when cooking dishes (Davydova, 2017).

Finally, another case that occurred in Amguema village characterizes local people as open to search for new taste experiences and able to enjoy their small food discoveries. Tatiana Vasil'evna Kaikavragyrgina and Marina Petrovna Dobrieva, who were aware of my interest in the Chukchi food issue, once again decided to make a small "Chukchi" feast for me. Thus, they came to visit me and brought stroganina from fish and whale fat with them. Having soy sauce on the table, I suggested trying to dip frozen fish in it. My guests agreed eagerly. They liked the taste very much. Without hiding the joy of their discovery, they said that they would definitely eat stroganina and whale fat with soy sauce from that time on (Davydova, 2018). 


\section{Food autonomy regimes}

Changes in the diet and methods of acquiring and cooking delicious and nutritious food went hand in hand with the transition to a new food autonomy regime. The concept of autonomy has been repeatedly used in anthropological literature. Yet, the authors put different meanings into it: political, economic, gender, territorial, and cultural (Beeson, 2000: 335-351; Gardner, 1991: 543-572; Graber, Long, 2009: 147-155; Grier, Kim, 2012: 1-34; Jones, 1971: 1-11; Lepowski, 1990: 35-50; Maclean, 1994: 667-688; Sahlins, 1972). The subjects of autonomy can belong to different social levels: villages, households, descent groups, families, etc., as well as individuals.

The concept of autonomy in anthropology is, firstly, linked to the discussions about the nature of egalitarianism. Some authors view egalitarianism as pursuit of autonomy, independence and individualism (Gardner, 1991: 543-572), whereas others regard "autonomous achievement" as prerequisite for social inequality (Helliwell, 1995: 359-375). Secondly, the concept of autonomy is used by anthropologists to study the interaction of small local communities and their economies with state power and global economic processes (Davydov, 2018: 46-65; Lepowski, 1990: 35-50; Maclean, 1994: 667-688).

In this paper, the study of autonomy regimes switching is considered in the context of state influence on the reindeer herders' way of life. However, the Soviet authorities' actions during Sovietization provoked the process of changing of autonomy regimes, the range of possible actors influencing the people's autonomy was not limited to the representatives of state authorities, but included various private companies, material objects, as well as the local residents.

By food autonomy I mean the ability of certain brigades, families, or even individuals to independently provide themselves with the desired tastes and feeling of satiety. Before collectivization, reindeer herding family groups, carried out autonomous production and consumption of food resources. The peoples' economic activity in the tundra, as well as kinship and friendship they maintained with coastal Chukchi and neighboring reindeer farms made it possible to be provided with food, that is, to get, preserve, cook delicious and nutritious food'. Using M. Sahlins' approach, we can state that food autonomy is a part of natural autonomy inherent in communities with a domestic mode of production (Sahlins, 1972: 95-99).

\footnotetext{
It is obviously not necessary to idealize the "traditional past": in the middle of the 20th century, some farms sometimes were short of food resources, in other words, felt hungry. This is particularly evidenced in V. G. Kuznetsova's notes (AMAE. F. K-1, inv. 2, file 388, 1.16 back page). This paper aims to show the practices of acquiring necessary food resource.
} 
It should be emphasized that food autonomy was achieved not by minimizing the consumed dishes and taste sensations during the meal, that is, monotony of the diet, but by maximizing the number of food resources, storage and cooking technologies, and integration of new products into the diet.

By the beginning of the $21^{\text {st }}$ century the situation has changed significantly. The changes can be viewed from both perspectives: one of the tundra and the other of the village. As already noted, a significant part of the Chukchi's diet today is held by "European" products sold in stores owned by private companies and partially subsidized by the state. In Amguema there are three grocery stores offering a wide range of food. Local residents buy bread, flour, cereals, pasta, dairy and flour products, sausages, cheeses, vegetables, fruits, canned food, sugar, salt, spices, seasonings, and sweets there. Transportation of many of these products from the village to the tundra is a part of modern reindeer herders' life. As a result, reindeer herders are connected by a network of relations about food.

Firstly, supply of reindeer herders and their food security depend on products delivery by the reindeer herding enterprise. Many tundra-dwellers remember the supply of the Soviet times when not only huge amounts of sugar, flour, cereals, pasta, but also jams, compotes, sausages, ham, fruits and vegetables, and even canned soups were delivered. People admit that they often threw food products because of their abundance. They say, those times were "abundant". In other words, they felt food security. Conversely, in the 1990s, when the state stopped investing in the development of this industry, people were on the verge of starvation. Thus, the view on the tundra dwellers' supply in its historical perspective shows that the people's food depends on the decisions and actions of the enterprise management, which, in turn, is due to state policy in relation to reindeer husbandry.

The activities of the reindeer herding collective farm, which is a municipal unitary enterprise now, affect the people's nutrition not only in the tundra, but also in the village. Amguema elderly residents, who spent their childhood not in reindeer herding brigades but in the village, say that they grew up on reindeer heads. Reindeer heads that remained after reindeer's mass slaughter in autumn were gradually taken by the local residents to be eaten at home and were the basis of their daily food. During the autumn-winter period people came to the place of slaughter with slightly fermented and frozen reindeer heads under the snow when it was necessary and took home as much as they needed. Today, some parts of the slaughtered reindeer, such as guts, heads, eyes, stomachs are also distributed. Some residents use this opportunity to obtain these 
products. Moreover, sometimes venison sold in the office of the enterprise is the only available meat for the villagers. Finally, in case of a threat of meat damage because of failure to transport it to Anadyr due to climatic conditions, the enterprise management distributes venison among the representatives of the indigenous peoples of Chukotka in Iul'tin district for free.

As for reindeer herders, currently they themselves make an order for the necessary products through the brigadier. Later the cost of products is deducted from their salaries. Purchase prices are lower than in the store; yet, the list of products for order through the enterprise is quite short (sugar, flour, salt, cereals, pasta, and vegetable oil) and does not meet all up-to-date food needs of the tundra people. Deliveries are regular, but sometimes there are delays caused by lack of equipment or weather conditions, for example.

In this regard, the tundra-dwellers look for alternative opportunities of necessary food purchase. In particular, pendulum trips between the village and the tundra have become part of the people's lives and the process of being provided with food. Reindeer herders regularly buy products in the village themselves and later take them to the tundra. In the cold (snow) season such trips are more frequent than in summer, as almost every family has got snowmobiles. As for cars and all-terrain vehicles that can drive in the tundra, reindeer herders rarely own them. Moreover, most of the brigades settle quite close to the village, sometimes only a few hours away by snowmobile or car.

In their mobility practices people are actively using the Iul'tin road, which significantly reduces travel time as it brings the brigade closer to the village. In addition, Amguema settlers, including reindeer herders, often purchase products in Egvekinot, the regional center. This practice is possible thanks to the Iul'tin road, on which Egvekinot and Amguema are located at a distance of $90 \mathrm{~km}$ from each other. A regular bus runs from Amguema to the regional center twice a week, the bus being nearly always full. Egvekinot residents call the days of arrival of the bus from Amguema "away" days (vyezdnye dni). They also emphasize that these days the shops are crowded with people coming from the village.

Amguema residents prefer buying products in Egvekinot for a number of reasons. They say that the choice is more varied, the products are fresher, and the prices are lower in the regional center. In fact, transport accessibility of Amguema is high (the village is located on the road), and the shops in the village belong to the network campaigns operating throughout Chukotka, including Egvekinot. Nevertheless, the 
range of products and prices of the village shops differ from the regional center, and the difference is great sometimes.

I asked people about this issue and possible ways of solving it, but most Amguema residents take the situation for granted. When shopping in local stores, I was always interested in the shelf life of products, the locals staring at me with curiosity, surprise or even irritation. One day a saleswoman joked about my actions, saying: "It is incredible to live in Chukotka and be afraid of expired products!" After this phrase I felt uncomfortable to ask about the expiration date of the products purchased.

Representatives of trading companies and sometimes local people say that the reasons for the food situation are remoteness of the village, severe climatic conditions, and high cost of transport infrastructure and its maintenance. Making their trip to Egvekinot, Amguema residents overcome the declared situation of the village "remoteness" and "inaccessibility" by themselves. The local residents, therefore, tend not to depend on the decisions and actions of other actors, the actors being trading companies. Yet, making these steps, they are involuntarily drawn into the circle of new dependencies. For example, a trip to Egvekinot is possible if the roads are cleared, the transport works properly, and the range of purchased products is ultimately determined by the range and prices in the local shops.

Thus, the sense of the local residents' food security depends on their mobility. In turn, mobility practices depend on its material component: all-terrain vehicles, snowmobiles, cars, and buses must be available and functional, the relevant parts, if broken, must be found, gasoline must be purchased, roads must be cleared and repaired. As for people without appropriate transportation means, they sometimes depend on the decisions of those who own any kind of transport. For example, Valery and Tamara, the reindeer herders mentioned above, asked the pensioner Vladimir Grigor'evich Omrychaivunu, an "UAZ" car owner, to take them to the village or the tundra. But, having entered the reciprocation relations, they felt the need to treat him with meat from the tundra.

The relationship of people in the tundra with people in the village should be regarded in a broader context than just mobility practices. The nutrition of people in the tundra partly depends on their relationship with those in the village. Reindeer herders do not always have the opportunity to leave the tundra for the village. They may have no transport, fuel or just time. In this regard, food parcels from the village to the tundra delivered with a convenient opportunity of some assistance, that is, in the case of transport sent to the brigades, play an important role in providing reindeer herders with 
food. Reindeer herders inform their friends and relatives about the products needed in the tundra via radio or through other people. Upon receiving the "order", people start tracking the time when transport is sent to the brigade and try to send the necessary products as quickly as possible. It is representative that the female reindeer herder, who came to Amguema from another district of Chukotka a couple of months ago and got a job as a reindeer herder, had neither relatives nor friends in the village and, thus, complained that she could not order products via radio through friends.

The tundra-dwellers' and village residents' relations and, more broadly, food autonomy can be viewed from the perspective of the village. One female reindeer herder once admitted that in the tundra they "miss" Russian products, which sometimes are not enough there, and, vice versa, they "miss" Chukchi food in the village. Indeed, almost all the locals get or at least seek to get venison from the tundra through their friends and relatives. In the village meat can be bought in the office of the "Amguema" enterprise. However, people prefer not to do this, as it is not always fresh due to its long storage in the refrigerator. Moreover, venison is often delivered to the office of the enterprise from the reindeer-slaughtering house, and the taste of this meat is very poor from the local people's point of view. According to the informants, during mass slaughter animals die hunted, sweated, frightened, and often hungry. As a result their meat smells bad. A good reindeer breeder, on the contrary, slaughters the reindeer in its well-fed and calm state. He strikes a blow so that death comes instantly. Thus, such meat is tasty and fragrant. If in winter the import of venison from the tundra is carried out regularly by snowmobiles, in summer it becomes a scarce product in many village houses. In August, upon my return from the tundra to the village with dried meat, a present, I decided to treat my friend living in the village. She was very happy, as she missed reindeer meat (Davydova, 2018).

People who spent their childhood and even adult life in the tundra suffer without the tundra food: fermented in the pit or dried over the yaranga's hearth meat, and traditional Chukchi dishes. It should be emphasized that it is difficult to get the products for many Chukchi dishes in the village: the reindeer stomach contents, blood, intestines, etc. While living in the village some elderly women who were reindeer herders still cook traditional dishes in Amguema, but they need products from the tundra, which they receive from their relatives and friends working in brigades. In this regard, relations with reindeer herders are also important for the villagers. Thus, they make their best to maintain them in every possible way. I got clearly convinced in it when I saw the genuine concern and involvement of one female resident of the village, who was 
engaged in organization of sending a parcel for her relative in the tundra. To do this she had to search for transport opportunity. This implies a continuous monitoring of vehicles and transportation means that travel to the tundra from the village. It is often difficult to do, as they lack any official information about this.

Thus, people in the village find themselves connected by quite numerous relations: having access to the products sold in stores, they also depend, like reindeer herders, on the trading companies' strategies and are also forced to look for a better choice in the regional center. Still, in addition to this, their food security depends on the reindeer herders themselves who slaughter or do not slaughter meat for their relatives and friends in the village. In other words, we can state the interdependence between the tundra-dwellers and the villagers.

I will draw a parallel with the mutual exchange of reindeer and coastal Chukchi, which existed in former times and is partly preserved to this day (Bogoras, 1904: 53; Krupnik, 2000: 50). Like reindeer herders and marine mammal hunters, the villagers and tundra-dwellers from different places with access to different resources cooperate to get a variety of tastes, a sense of satiety and food security. In this sense, all Amguema residents, who are in brigades or the settlement, become more autonomous and independent from products supply to local shops and food distribution systems in the reindeer husbandry enterprise. This is due to intensification of exchange relations between the village and the tundra.

\section{Conclusion}

In the Soviet and post-Soviet periods, there were significant changes in the diet of indigenous people of Chukotka. The composition of consumed products has changed; the forms of acquisition, preservation and use of food resources have been transformed. But as in previous times, people tend to cook the dishes which are nourishing, tasty and varied in taste. Yet, if in the pre-Soviet period this goal was achieved mainly through the use and combination of different cooking technologies, as well as accumulation of local resources, today it is, in particular, due to the inclusion of "Russian" products in the diet that are purchased in stores but not created in the domestic production. The change of food autonomy regime became the consequence of changing the ways of food resource maximization. By organizing a trip to Egvekinot, buying a car or a snowmobile, entering into reciprocal relations with people in the village or the tundra, local residents seek for an independent supply of food resources. However, in reality each such action entails a new wave 
of dependencies. People become involved in the whole network of relations with the reindeer herding enterprise, the state (in the form of its infrastructure), trade companies, material components of mobility, which eventually limit their food autonomy.

\section{References}

Afanas'eva, G.I., Simchenko, Iu.B. (1993). Traditsionnaia pishcha beregovykh i olennykh chukchei [Traditional food of coastal and reindeer Chukchi]. In Sibirskii etnograficheskii sbornik [Siberian ethnographic collection], 6 (1), 56-100.

Appadurai, A. (1986). On Cultural Authenticity. In Anthropology today, 2 (4), 25.

Beeson, M. (2000). Mahathir and the Markets: Globalisation and the Pursuit of Economic Autonomy in Malaysia. In Pacific Affairs, 73 (3), 335-351.

Bogoras, W. (1904). The Chukchee. Material Culture. New York, Leiden, G.E. Stechert, E. J. Brill Ltd, 276 p.

Chukotskii iazyk [The Chukchi Language]. Available at: http://charles.weinstein. free.fr/chukches/LEX/LxT-Tajnat_aliment.html (accessed 16 November 2018).

Davydov, V.N. (2018). Strategii ispol'zovaniia prostranstva i rezhimy avtonomnosti: Otnosheniia evenkov i gosudarstva na Severnom Baikale [Strategies of using the space and autonomy regimes: The relations of Evenkis and the state in the Northern Baikal]. In Etnografiia [Ethnography], 2, 46-65.

Davydova, E.A. (2018). "Edinstvennoe $\mathrm{v}$ chem ia bolee menee preuspela - v osvoenii chukotskoi kukhni”: Polevaia rabota V.G. Kuznetsovoi v Amguemskoi tundre ["The only thing I have more or less succeeded in is the Chukchi cuisine": V.G. Kuznetsova's field work in the Amguema tundra]. In Materialy polevykh issledovanii MAE RAN [Field research materials of MAE RAS], 18, 128-147.

Davydava, E.A. (2019). Kholodil'nik, sol' i sakhar: dobycha i tekhnologii obrabotki pishchi na Chukotke [Refrigerator, salt and sugar: Food acquisition and processing technologies on Chukotka]. In Sibirskie istoricheskie issledovaniia [Siberian historical studies], 2, 143-161.

Davydova, E.A. (2017, 2018). Polevye materialy avtora. Ekspeditsii na Chukotku [The author's field materials. Expeditions to Chukotka].

Gardner, P. (1991). Forager's pursuit for individual autonomy. In Current anthropology, 32 (5), 543-572.

Golbtseva, V.V. (2017). Prazdnichnye i zhertvennye bliuda u chukchei i eskimosov Chukotki [Festive and sacrificial meals among the Chukchi and the Eskimo in 
Chukotka]. In Prazdnechnaia i obriadovaia pishcha narodov mira [Festive and ritual food of the peoples of the world]. Moscow, Nauka, 249-270.

Graber, K., Long, J. (2009). The Dissolution of the Buryat Autonomous Okrug in Siberia: Notes from the Field. In Inner Asia, 11 (1), 147-155.

Grier, C., Kim, J. (2012). Resource Control and the Development of Political Economies in Small-Scale Societies. In Journal of Anthropological Research, 68 (1), 1-34.

Helliwell, C. (1995). Autonomy as Natural Equality: Inequality in 'Egalitarian' Societies. In The Journal of Royal Anthropological Institute, 1 (2), 359-375.

Jones, D. (1971). Village Autonomy, Cultural Status and Self Perception. In Anthropological Quarterly, 44 (1), 1-11.

Kallinikov, N.F. (1912). Nash krainii Severo-Vostok [Our extreme northeast]. St. Petersburg, Tipografiia morskogo minesterstva, $256 \mathrm{p}$.

Kozlov, A., Nuvano, V., Vershubsky, G. (2007). Changes in Soviet and Post-Soviet Diets in Chukotka. In Etudes/Inuit/Studies, 31 (1-2), 103-119.

Krupnik, I.I. (2000). Reindeer Pastoralism in Modern Siberia: Research and Survival During the Time of Crash. In Polar Research, 19 (1), 49-56.

Kuznetsova, V.G. (1948-1951). Materialy iz poezdki k chukcham [The materials from the trip to the Chukchi]. In Arkhiv museia antropologii i etnographii imeni Petra Velikogo (Kunstkamera) RAN [The Archive of Peter the Great Museum of Anthropology and Ethnography]. F. K-1, 2, 334-403.

Lepowski, M. (1990). Big Men, Big Women, and Cultural Autonomy. In Ethnology, 29 (1), 35-50.

Maclean, N. (1994). Freedom or Autonomy: A Modern Melanesian Dilemma. In Man, New Series, 29 (3), 667-688.

Mikhailova, E.A. (2015). Skitaniia Varvary Kuznetsovoi [Wanderings of Varvara Kuznetsova]. St. Petersburg, MAE RAN, 189 p.

Protokoly sessii sel'skogo soveta za 1954 god [The minutes of the village council sessions in 1954]. In Arkhiv administratsii gorodskogo okruga Egvekinot [The archive of the administration of Egvekinot].

Sahlins, M. (1972). Stone Age Economics. Chicago, New York, Aldine Atherton, 348.

Yamin-Pasternak, S. (2008). From Disgust to Desire: Changing Attitudes toward Beringian Mushrooms. In Economic botany, 62 (3), 214-222.

Yamin-Pasternak, S., Kliskey, A., Alessa, L., Pasternak, I., Schweitzer, P. (2014). The Rotten Renaissance in the Bering Strait: Loving, Loathing, and Washing the Smell of Foods with a (Re)Acquired Taste. In Current Anthropology, 55 (5), 619-646. 


\title{
Пища как энергетический ресурс: \\ паттерны получения и использования \\ продуктов питания на Чукотке
}

\author{
Е.А. Давыдова \\ Музей антропологии и этнографии \\ им. Петра Великого РАН (Кунсткамера) \\ Россия, 199034, Санкт-Петербург, \\ Университетская наб., 3 \\ Чукотский филиал федерального государственного \\ автономного учреждения высшего образования \\ «Северо-Восточный федеральный университет \\ имени М.К. Аммосова» \\ Россия, 689000, Анадырь, ул. Студенческая, 3
}

В статье исследуются изменения, произошедшие в диете жителей Чукотки в $X X$ ХХІ вв. Источниковой базой работы стали полевые и архивные материаль, относящиеся, главным образом, к амгуэмской тундре. Сравнивая традиционные и современные пищевые практики в данном регионе, автор фокусируется на способах приобретения, сохранения, обработки и приготовления пищевых ресурсов. В ходе анализа сделан вывод, что изменения в пищевых практиках и диете сопровождались переходом к новому режиму пищевой автономности. Сегодня, как и в прежние времена, люди стремятся создать сытные, вкусныле и разнообразные по вкусу блюда. Но если в досоветский период люди достигали данной иели с помощью использования различных технологий приготовления пищи, аккумулирования локальных ресурсов и сочиальных связей с береговыми чукчами, в настоящее время, наряду с перечисленными стратегиями, местные жители максимизируют пищевые ресурсы, включая в рацион питания продукты, приобретаемые в магазине, а не создающиеся в рамках домашнего производства. В результате формируется целая сеть отношений по поводу пищи с оленеводческим предприятием, государственной инфраструктурой, торговыми компаниями, материальными компонентами мобильности, тундрой и селом, которая влияет на чувство пищевой безопасности местных жителей и в конечном счете лимитирует их пищевую автономность.

Ключевые слова: антропология пищи, энергия, ресурсы, оленеводство, коренные народы, Чукотка, Арктический регион.

Исследование выполнено за счет гранта Российского научного фонда (проект № 17-78-10125).

Научная спещиальность: 07.00.07 - этнография, этнология, антропология. 